уміннями організовувати знання в систему, сформованістю раціональних способів навчальної роботи.

\title{
Література
}

1. Власенко К. Формування умінь i навичок студентів вищих навчальних закладів у процесі евристичної діяльності / К. Власенко // Рідна школа. - 2005. № 4. - С. 55-60. 2. Гаврищак Г. Р. Компетентність та ключові компетенції викладача ВНЗ / Г. Р. Гаврищак // Матеріали регіонального науково-практичного семінару «Професійні компетенції та компетентності вчителя» (28-29 листопада 2006 р.) C. 31-32. 3. Герлянд Т. Сучасні аспекти формування професійної компетентності майбутніх викладачів спецдисциплін/ Тетяна Герлянд// Педагогіка і психологія професійної освіти : науково-методичний журнал. - 2010. - № 1-2. - С. 37-43. 4. Кадемія М. Й. Сучасні методи та інноваційні технології навчання / М. Ю. Кадемія // Професійно-технічна освіта. - 2004. - № 2. - С. 49-51. 5. Марігодов В. К. Системний підхід до підготовки проблемної лекції / В. К. Марігодов // Нові технології навчання: [наук.-метод. зб.] / М-во освіти і науки України, Ін-т інновац. технологій і змісту освіти. - К., 2007. - Вип. 46. - С. 10-16. 6. Погорслова Л. В. Деякі аспекти творчої діяльності в процесі навчання / Л. В. Погорєлова // Пробл. інж.-пед. освіти : [зб. наук. пр.] / Укр. інж.-пед. акад. - Х., 2007. - Вип. 18-19. - С. 125-132.

УДК 13.04

Лоліта Маліцька

\section{ВПЛИВ ЕТНОСТЕРЕОТИПІВ НА ФОРМУВАННЯ ОСОБИСТІСНОЇ СПРЯМОВАНОСТІ}

Маліцька Л. Б. Вплив етностереотипів на формування особистісної спрямованості.

Статтю присвячено актуальній проблемі етнічної ідентифікації в умовах соціально-політичної кризи. Розглядаються можливості соціалізації особистості, роль етностереотипів у цьому процесі, вплив етнічної ідентифікації на самореалізацію особистості в сучасному суспільстві.

Ключові слова: етнічна ідентифікація, етнічні стереотипи, соціалізація, самореалізація.

Малицкая Л. Б. Влияние этностереотипов на формирование личностной направленности.

Статья посвящена актуальной проблеме этнической идентификации в условиях социально-политического кризиса. Рассматриваются возможности социализации личности, роль етностереотипов в этом процесе, влияние этнической идентификации на самореализацию личности в современном обществе.

Ключевые слова: этническая идентификация, этнические стеретипы, социализация, самореализация.

Malitska L. B. Influence of ethnic stereotypes on forming personal orientation.

The article deals with actual problems of ethnic identification under conditions of the possibilities of personality's socialization, the role of ethnic identification in self-realization of personality at the modern society.

Key words: ethnic identification, ethnic stereotypes, socialization, self-realization. 
Життя сучасної людини зумовлене насамперед позаетнічними характеристиками - рівнем освіти, фахом, рівнем добробуту тощо. Однак етнічність повністю не зникає, а перебуває в латентному стані і здатна виявлятися в актуальних моментах життя. Нині практично немає моноетнічних середовищ. Процес онтогенезу відбувається в поліетнічному оточенні. у такий спосіб на формування особистості впливають як генетичні засадові, так і сформовані у суспільстві етнічні стереотипи. Етнічні стереотипи виявляються як жорстко фіксована етнічна настанова, що безпосередньо регулює сприйняття, поведінку й інтерпретацію поведінки оточення. Етнічні стереотипи сприйняття пов'язані насамперед 3 узагальненим та схематизованим описом властивостей і характеристик власної етнічної спільноти. На засадах етнічних стереотипів формується особистісна етнічна ідентичність. На думку Т. Стефаненко [5], розмежовують три типи етнічної ідентичності людини в поліетнічному середовищі: 1) моноетнічна ідентичність - людина однозначно ототожнює себе $з$ конкретним народом; 2) біетнічна ідентичність - людина одночасно зараховує себе до двох етнічних груп; найчастіше такий вид ідентичності виникає на основі того, що батьки належать до різних національностей; 3) маргінальна етнічна ідентичність - людина не може однозначно визначитись у власній етнічній приналежності. Г. Солдатова [4] уважає, що етнічний феномен в особистості формується на засадах трьох взаємопов'язаних процесів: 1) етнічної ідентифікаціїототожнення й самовизначення особистості за рахунок етнічної групи; 2) міжетнічної диференціації - поділу етнічних груп на власну й інших, та усвідомлення міжетнічних розбіжностей; 3) усвідомлення ставлення як до власної, так і до інших етнічних груп. Змістом етнічної ідентичності є як свідомі, так і несвідомі компоненти.

Психолог 3. Фрейд [5] у психологічних творах, присвячених мазохізму, наголошує на тому, що «моральний мазохізм - переважаюча особистісна якість багатьох слов'янських типів характеру, яку можна вважати національною особливістю». Він уважає, що «моральний мазохізм»- найважливіша форма вияву мазохізму, що виявляється здебільшого як вияв несвідомого через почуття провини. На думку 3. Фрейда, він найменше пов'язаний $з$ людською сексуальністю. У ньому не культивуються суб'єктсуб'єктні відносини як чинник мазохістських схильностей. Змістове навантаження переживань відсторонене. Головне значення має сам факт страждання як самоціль, незважаючи на те, що його спонукає чи то інша особа, чи абстрактні сили й обставини. Руйнівні потяги спрямовані на внутрішній світ проти власного «Я». Користі від цього немає ні для моралі, ні для особистості. Хоч індивід і має можливість, незважаючи на власний мазохізм, зберегти - повністю або частково - свою моральність, більша частина його сумління може пропасти в мазохізмі. «Моральний мазохізм» спокушає до «гріховних» вчинків, які в подальшому повинні компенсуватися наріканнями садистського сумління та покаранням, що походить від великої батьківської сили долі. Щоб спровокувати покарання з боку батьківського представника, мазохіст повинен робити щось нераціональне, працювати попри власну вигоду, руйнувати перспективи, котрі відкриваються йому в реальному світі, а як крайня міра - покінчити з власним існуванням.

Обмеженість інформації 3 окресленої проблеми спонукала нас провести дослідження особистісних характеристик самовизначення у студентському середовищі. Юнацький вік був обраний як період прийняття відповідальних рішень, що визначають все подальше життя людини: обрання професії і свого місця в суспільстві, визначення сенсу життя, формування світогляду та життєвої позиції, створення сім'ї. Найважливіший процес юнацького віку - становлення самосвідомості, сталого образу власної особистості, власного «Я». Формування 
самосвідомості при цьому відбувається одночасно в трьох напрямках. По-перше, це відкриття власного внутрішнього світу. Юнаки починають сприймати свої емоції не як похідне від зовнішніх подій, а як стан свого «Я». Виникає почуття відмінності від інших, несхожості, власної особливості, інколи почуття самотності. По-друге, з'являється усвідомлення невідворотності часу, розуміння скінченності існування. Саме $з$ розумінням обмеженості життєвого шляху виникає потреба з'ясувати його сенс, власні перспективи, майбутнє, мету існування. Поступово з мрій, де все цілком можливе, та абстрактного ідеалу окреслюються більш-менш реалістичні плани діяльності, з яких і треба обирати найперспективніший. Життєвий план охоплює всю сферу особистісного самовизначення: моральний образ, стиль життя, рівень домагань, обрання професії й місця в суспільній ієрархії. Усвідомлення мети, життєвих намірів, життєвого плану- важливий елемент самоусвідомлення особистості. По-третє, формується цілісне уявлення про самого себе, причому спочатку усвідомлюються анатомічні особливості, зовнішність, привабливість, а потім вже моральнопсихологічні, інтелектуальні, вольові якості. На засадах аналізу досягнутих результатів в різних видах діяльності, врахування думок інших про себе та самоспостереження, самоаналізу своїх якостей і здібностей формується самоповага узагальнене ставлення до себе.

Соціальні зміни та потрясіння сучасності зумовили те, що особистість опинилася у стані, що характеризується кризою етнічної ідентичності. Н. Лебедєва [2] виокремлює такі ознаки кризи: 1) втрата позитивного сприйняття своєї етнічної приналежності; 2) переживання негативних почуттів, пов'язаних саме 3 етнічною приналежністю; 3) незадоволеність громадянською приналежністю; 4) негативна або зверхньо позитивна (захисна) етнічна ідентичність; 5) інтолерантність щодо інших етносів; 6) втрата почуття патріотизму; 7) втрата сенсу життя.

Відхилення від нормальної позитивної етнічної ідентифікації, на думку Г. Солдатової, можуть бути п'яти типів: 1) етнічна індиферентність (космополітиз) виникає тоді, коли особистісна ідентичність стає набагато важливішою, ніж етнічна; 2) гіпоідентичність (етнонігілізм) - небажання підтримувати власні етнокультурні цінності, іноді негативізм стосовно власного народу; 3) гіперідентичність характеризується намаганням етнічного домінування, схильністю до етноцентризму, що виявляється у трьох видах: а) етноегоїзм - відносно лояльний вид, що найчастіше виявляється на вербальному рівні у вигляді напруження i дратівливості під час спілкуванні з представниками іншого народу; б) етноізоляціонізм - переконаність в унікальності власного народу і зверхньому ставленні до інших; в) національний фанатизм - готовність до будь-якої діяльності в ім'я етнічних інтересів, виправдання будь-яких жертв.

Соціально-історичні умови, у яких проходить процес соціалізації особистості, суттєво впливає на її успішність. Так за теорією етногенезу Л. Гумільова [1], у період бурхливого розвитку етносу в суспільстві починають домінувати цінності, що акцентують значення особистісного успіху, ризику й добробуту в різних галузях суспільного життя, така спрямованість зумовлює до стимуляції прогресивного розвитку етносу. При цьому, найбільш вдало соціалізованими стають особистості 3 яскраво вираженою індивідуальністю, самореалізація яких обумовлена насамперед суспільними інтересами. Такі люди ототожнюють себе з людством, підкорюючи цим двом домінантам сталі групові норми, тобто в них виразно сформованими $є$ саме особистісний та загальнолюдський рівень ідентичності.

У стабільні періоди розвитку суспільства більш соціально адаптованими 
виявляються люди, у яких переважає груповий рівень ідентичності. Їм притаманні соціотипічні форми поведінки, що виражають спрямованість системи до збереження. У кризові історичні моменти буття мають попит різні типи особистостей: 3 одночасним загальнолюдським та індивідуально-особистісним рівнем ідентичності; що намагаються врятуватися від суспільної негоди у звичних стереотипах групових норм, що притаманні стабільному етапу розвитку соціуму. В умовах суспільної кризи домінування такого типу особистостей призводить до пошуку «зовнішніх ворогів», визнання переваг виключно своєї (національної, професійної, вікової, територіальної) групи. Соціальна криза характеризується, як правило, змінами «ідеологічних цінностей» суспільства, причому динаміка цього суспільно-історичного процесу може не збігатися 3 індивідуальними адаптаційними процесами $\mathrm{i}$ можливостями особистості. Під час руйнування «ідеологічної цілісності» виникають додаткові перешкоди, коли окремі найбільш обдаровані індивіди впадають у стан психосоціального мораторію, що виражається у відстороненні від загальної системи суспільних цінностей і формуванні власної. Молоді люди, які перебувають у цьому стані, можуть сформувати як позитивну, так i негативну ідентичність, котра представляє собою два полюси континуума. Його центр складають такі типи світогляду, які не сприймають існуючу систему цінностей, водночас не вступають 3 нею у відвертий конфлікт. На негативному полюсі цього континуума знаходяться молоді люди, що мають власну систему норм, традицій, поглядів, відповідно до яких вони не тільки не сприймають загальноприйняті соціальні норми, але і порушують їх, створюючи тим самим злочинну субкультуру.

У стан соціального мораторію може впасти не тільки одна людина або група людей, a і ціле покоління, юність якого прийшлася на період буремних соціальних змін.

Соціалізація, як особистісний процес, грунтується на властивостях, притаманних цій особистості (здібностям, зовнішнім даним, рівнем конформності, комунікабельності, індивідуальному рівню ідентичності), тобто спрямованості на розвиток власних здібностей, усвідомленню власного життєвого шляху як унікального. Критеріями соціалізованої особистості можна вважати: зміст сформованих установок, стереотипів, цінностей, картин світу; адаптованість особистості, її нормотипічна поведінка, стиль життя; соціальна ідентичність (групова і загальнолюдська). Головним критерієм соціалізованості особистості $\epsilon$ не рівень іiі конформізму, пристосовницьких якостей, а незакомплексованість, упевненість, самостійність. Головна мета соціалізації не в ії уніфікації, а в задоволенні потреби в самореалізації.

Досліджуючи процес етнічної ідентифікації в юнацькому віці, ми орієнтувалися на теорію соціального порівняння Леона Фестінгера [6]. Основні положення цієї теорії полягають у тому, що:

1. Люди потребують оцінки власних суджень і здібностей.

2. Оцінюючи самих себе, люди спираються на процеси соціального порівняння, і чим більш доступні об'єктивні, несоціальні способи оцінки, тим більше люди спираються на ці процеси. Чим меншою є однозначна і структурована об'єктивна реальність, тим частіше люди надають перевагу процесам соціального порівняння.

3. Людям притаманне намагання порівнювати себе $з$ тими, хто на них подібний. Чим більше судження і здібності тих, хто поряд, подібні до суджень і здібності певної людини, тим більше вони підходять на роль референтної групи. Людина не порівнює себе $з$ тими, хто разюче відрізняється від неї.

4. Чим більше здібності i судження людини відповідають судженням i 
здібностям тих, 3 ким вона себе порівнює, тим більш стабільна, коректна і точна інформація, яку надає це порівняння, тобто воно достатньо інформативне.

5. Чим вище потреба людини в оцінці власних суджень і здібностей, тим більше вона схильна до того, щоб бути привабливим для однодумців і до зменшення різниці між собою і ними. Людина робить це для збільшення соціального порівняння між собою і оточуючими.

Динамічний перехід від одного суспільного устою до іншого спричинив розмивання між етнічною ідентичністю й особистісною. Інформаційне поле перенасичене рекламною демонстрацією успішності тієї чи тієї національної спільноти, а національні, етнічні стереотипи, що пропонуються для засвоєння молоді, не адекватні сучасному темпу життєдіяльності. У своєму дослідженні ми пропонували студентам визначити, які властивості саме національного характеру можуть сприяти самореалізації людини в країні і за кордоном. Відповіді характеризувалися відвертою полярністю. 3 чого можна зробити висновок про достатньо високий рівень конформності, тобто залежно від зміни ситуації людина має намір радикально змінюватись, не обстоюючи власну особистісну цілісність. Ця цілісність має відносні межі, і в ній не задіяні етнічні стереотипи. Найважче студентам було визначитись, які 3 національних стереотипів будуть «конкурентно спроможні» порівняно з етнічними стереотипами інших національностей. Достатня поінформованість торкалася виключно слов'янських народів 3 переважною оцінкою, як «друзів нещастя». Закордонна версія самореалізації розглядається як більш бажана, але проблематична. Студенти ставлять успішність адаптації в іншому етносередовищі в залежність від ефективного наслідування й асиміляції, визнаючи за цими етносами домінуючу функцію. При цьому, прогнозувати можливості і наслідки наслідування для власної етноідентифікації спромігся мінімальний відсоток студентів. Слід відмітити, що оцінки етностереотипів були здебільшого суб'єктивно-емоційного характеру і збігалися 3 характерологічними особливостями конкретних значущих особистостей. При цьому позитивним ознакам надавалася більш широка характеристика, ніж негативним. Загалом, визначалася несформованість образу як окремого представника етносу, так і етнічної спільноти, що негативно впливає на процес соціального порівняння й етноідентифікації.

Найбільше занепокоєння викликає те, що етностереотипи не розповсюджуються на різноманітні сфери сучасної людської діяльності. Світ пропонує молодій людині багатогранний спектр професійної самореалізацій. У ньому вже склалися сталі стереотипи, що прив'язують певну національність до успішності в окремих галузях (німці - машини, японці - техніка тощо).

Такі стереотипи знижують рівень тривожності і негативних очікувань та підвищують рівень домагань у юнацтва. Наші студенти, визнаючи за собою наявність розуму i здібностей, не мають впевненості в тому, що вдасться їх реалізувати особливо на теренах рідної держави. Це спричиняє зайву невротизацію і програмує упереджено низький рівень самооцінки. Аналогічна невизначеність стосується й особистого життя. Ми запропонували студентам скласти оптимістичний і песимістичний сценарії їх майбутнього сімейного життя на засадах етностереотипів. Виявилося, що уявлення про національний сімейний устрій в край обмежені і грунтуються на знаннях з шкільного курсу класичної літератури 3 домішками релігійних забобонів. Звісно, такого роду стереотипи не має приваблюючого значення. У певної частини студентства під впливом сучасної української модернової літератури сформувалися фатально песимістичні прогнози стосовно перспектив сімейного життя (О. Забужко «В Україні чоловік або раб, або кат») і мінімальні позитивні очікування 
від подружнього життя та виховання нащадків. У цьому контексті йде репродуктивне наслідування іноземних етностереотипів, що призводить до невиправданих очікувань i неадекватної оцінки своїх ролевих обов'язків.

Людство сформувало різні моделі особистості залежно від етнокультурної специфіки. І. Кон [3] запропонував порівняльну характеристику західної і східної моделей особистості. Західна модель людини $є$ активно-предметною. Особистість формується у процесі зовнішньої діяльності, в діях, вчинках, завдяки операціям 3 предметами. Східна модель особистості не надає головного значення предметній діяльності, вважаючи, що творча активність, як основа особистості, розвивається лише у внутрішньому духовному просторі і пізнається не практикою, а в процесі миттєвого осяяння, інсайту.

Західна модель обстоює самоцінність особистості. Тобто особистість для неї - це система, внутрішній космос. Східна етнокультурна модель, особливо японська і китайська, підкреслює залежність особистості від певної соціальної групи, вимагаючи приналежності до цієї групи, втілення іiі ідеалів, норм, цінностей. Тобто особистість це атом у великому світі людей.

Західна модель розуміє особистість як цілісну систему. Роздробленість, численність «Я» сприймається європейцями як ненормальність, як розлад, що потребує лікування. В японській моделі, навпаки, особистість сприймається як численність, сукупність різних обов'язків стосовно суспільства, батьків, фірми, сім'ї, самого себе.

Західна етнокультурна модель оцінює особистість в цілому, іiі вчинки в різних ситуаціях вважаються похідною однієї і тієї ж сутності. На Сході уникають судити про людину в цілому, розділяючи ії поведінку на окремі галузі, у кожній з яких діють власні закони і норми поведінки.

На Заході люди намагаються пояснювати поведінку людей, виходячи 3 розуміння мотивів тієї чи іншої діяльності. Для них, насамперед, важливо зрозуміти, чому людина поводиться таким чином: 3 почуття вдячності, патріотизму, корисливих намірів тощо. Важливим уважається моральний аспект вчинків людини. На Сході поведінка оцінюється загальними правилами і нормами. Важливо не те, чому людина так вчиняє, а відповідає іiі поведінка загальноприйнятим в цьому етносі нормам i правилам.

Людина західної культури чітко усвідомлює власну відмінність від інших, свою «замість». Для людини східної культури важлива реалізація себе лише як частини цілого певної спільноти. Люди Сходу більше стурбовані збереженням власної групової ідентичності. На Заході люди зорієнтовані на самореалізацію. Особистісні особливості людей західної і східної культур обумовлені насамперед різницею в системі цінностей.

Сучасна глобалізація світу спонукає до трансформації етностереотипів. Еволюційна їх трансформація має позитивний контекст, оскільки підвищує адаптаційну спроможність етносу. Надає можливість відчувати себе співучасником світових суспільно-історичних процесів, пов'язуючи попередні надбання етносу 3 сучасними і прогностичними. Отже, створюється певний психотерапевтичний ефект стабільності, котрий забезпечується етноідентичністю. Навіть при достатньо тривалому періоді політичних кризових явищ, етноідентифікованість суспільства здатна знизити рівень його невротизації. Етностереотипи, як гарантовано працюючі $\mathrm{i}$ перевірені часом схеми поведінки в період суспільно-політичної кризи, можуть бути чи не єдиним стабілізуючим психічний стан чинником. Тому несформованість етностереотипів 
у сучасної молоді, як наслідок швидкісного переходу від імперської провінції до незалежності, $\epsilon$ додатковим дезадаптуючим чинником на тлі загальної суспільної невизначеності. 3 ним пов'язані намагання молоді ідентифікувати себе 3 деструктивними культами, що виявляються в етнічних химерах на межі суперетнічних систем. Химера - це форма контакту несумісних етносів різних суперетнічних систем, за якого зникає ї своєрідність. Химера характеризується як загал деетнізованих людей, етнічних маргіналів, що втратили рідні етнічні стереотипи та етнічні традиції. Результатом такої етнічної дисфункції стає психічна дезадаптація 3 відповідними розладами нервової системи людини. На відміну від етносу, химера не може розвиватися, а паразитує деякий час у його тілі. Здебільшого вони складаються під час вторгнення представників одного суперетносу на терени проживання іншого, після чого агресор намагається жити не за рахунок освоєння ландшафту, а за рахунок переможених. Химера як псевдоетнічна спільнота, протиставляє себе всім, відкидаючи традиції й заміняючи їх постійним оновленням «новизни». Тобто в химери немає вітчизни, що робить іï чутливою до негативного світосприймання. Тому химери - поживне середовище для виникнення антисистем, що будуються за принципом обману - стереотип як генерального стереотипу поведінки i найчастіше оселяються у мегаполісах, портових, прикордонних містах. Звичайно, не всі деетнізовані люди входять до антисистем, а виключно ті, кому притаманне негативне світосприймання. Коли під впливом яких-небудь зовнішніх чинників негативне світосприймання починає домінувати, етнос або його частина мутує в антисистему.

\section{Література}

1. Гумилев Л. Н. Этногенез и биосфера Земли / Л. Н. Гумилев. - Л. : АйрисПресс, 2007. - 560 с. 2. Лебедева Н. М. Базовые ценности русских на рубеже XX1 века / Н. М. Лебедева // Психологический журнал. - 2000. - Т. 22. - № 3. - С. 75-89. 3. Кон И. С. Социология личности / И. С. Кон. - М. : Политиздат, 1967. - 383 с. 4. Солдатова Г. У. Психология межэтнической напряженности / Г. У. Солдатова. М. : Смысл, 1998. - 386 с. 5. Фрейд 3. Работы о мазохизме / З. Фрейд; [пер. с нем.] / 3. Фрейд. - М. : РИК «Культура», 1992. - 384 с.

УДК 681.515:378

Людмила Цвіркун

\section{ІНФОРМАЦІЙНО-КОМУНІКАЦІЙНІ ТЕХНОЛОГІЇ ЯК ЧИННИК МОТИВАЦІЇ У НАВЧАННІ ГРАФІЧНИХ ДИСЦИПЛІН}

Цвіркун Л. О. Інформаційно-комунікаційні технології як чинник мотивації у навчанні графічних дисциплін.

У статті розглянуто можливості інформаційно-комунікаційних технологій, що сприяють посиленню уваги та інтересу до навчання графічних дисциплін за рахунок наочності і візуалізації. 3'ясовано, що виконання моделюючих завдань, інженернографічних робіт та навчальних проектів за допомогою сучасних графічних програм сприяє посиленню мотивації до графічної підготовки.

Ключові слова: інженер, графічні дисципліни, інформаційно-комунікаційні технології, мотивація, проектно-конструкторська компетентність.

Цвиркун Л. А. Информационно-коммуникационные технологии как фактор мотивации в обучении графических дисциплин.

В статье рассмотрены возможности информационно-коммуникационных технологий, способствующие усилению внимания и интереса к изучению 